\title{
Association between intimin (eae) and EspB gene subtypes in attaching and effacing Escherichia coli strains isolated from diarrhoeic lambs and goat kids
}

\author{
D. Cid, ${ }^{1}$ J. A. Ruiz-Santa-Quiteria, ${ }^{1}$ I. Marín, ${ }^{2}$ R. Sanz, ${ }^{1}$ J. A. Orden, ${ }^{1}$ \\ R. Amils ${ }^{2}$ and R. de la Fuente ${ }^{1}$
}

Author for correspondence: R. de la Fuente. Tel: +34 91 3943703. Fax: +34 913943908. e-mail: rifuente@eucmax.sim.ucm.es

1 Departamento Patología Animal I, Facultad de Veterinaria, Universidad Complutense, 28040 Madrid, Spain

2 Centro de Biología Molecular, Universidad Autónoma de Madrid, Cantoblanco, 28049 Madrid, Spain
Attaching and effacing Escherichia coli (AEEC) strains isolated from diarrhoeic lambs and goat kids were characterized for intimin (eae) and EspB (espB) gene subtypes by PCR and sequencing, and for genetic relatedness by PFGE. Fifty (23 ovine and 27 caprine) AEEC strains of 398 (246 ovine and 152 caprine) analysed were detected by colony blot hybridization. These strains were epidemiologically unrelated since they were isolated from different outbreaks of neonatal diarrhoea over a long period. Ovine AEEC strains belonged to serogroups 02, 04, 026, 080, 091 or were untypable, and caprine strains belonged to serogroups 03,0153 and 0163 . Two intimin subtypes were detected among the ovine and caprine strains studied. Most of the strains (43/50) had the $\beta$ type intimin gene, but seven ovine strains possessed a variant $\gamma$ type intimin gene $\left(\gamma_{v}\right)$. Analysis of deduced amino acid sequences of the eae gene revealed that the sequences of $\beta$ intimin of ovine and caprine strains were virtually identical to those of $\beta$ intimin of rabbit EPEC, human EPEC clone 2 and swine AEEC, whereas the $\gamma_{v}$ intimin present in seven ovine strains had $75-76 \%$ identity with $\gamma$ intimin of human EHEC clone 1 strains, and $96 \%$ of identity with intimin of the human EHEC strain 95NR1 of serotype 0111:H-. A PCR test was developed to identify the three different espB gene subtypes, espB of human EPEC clone 1 (espB $\alpha$ ), espB of human EHEC clone 1 (espB $\gamma$ ) and espB of rabbit EPEC and human EPEC clone 2 (espB $\beta)$. There was close correlation between the intimin $\beta$ type and the espB $\beta$ gene subtype in the ovine and caprine AEEC strains. The seven ovine strains possessing the $\gamma_{v}$ intimin gene possessed the espB $\alpha$ gene subtype. None of the strains studied possessed the espB $\gamma$ gene found in human 0157:H7 EHEC strains. PFGE analysis of genomic DNA of selected strains showed a great diversity among strains. Cluster analysis of PFGE patterns showed greater divergence between strains with the $\gamma_{v}$ intimin gene than between strains with the $\beta$ intimin gene. This study showed that most of the AEEC strains isolated from diarrhoeic lambs and goat kids possessed $\beta$ intimin and espB genes identical to those of rabbit EPEC, and they may be associated with enteric disease in small ruminants.

Keywords: pulsed field gel electrophoresis, attaching and effacing Escherichia coli strains, enteropathogenic E. coli, diarrhoea, adherence

Abbreviations: $A E$, attaching and effacing; $A E E C$, attaching and effacing E. coli; $C N F$, cytotoxic necrotizing factor; EHEC, enterohaemorrhagic E. coli; EPEC, enteropathogenic E. coli; Esp, EPEC secreted protein; HC, haemorrhagic colitis; HUS, haemolytic uraemic syndrome; LEE, locus for enterocyte effacement; Stx, Shiga toxin; VT, verotoxin.

The GenBank accession numbers for the sequences reported in this paper are AF253560 (eae gene of strain CK379), AF253561 (eae gene of strain CL559), and AF254454, AF254455, AF254456 and AF254457 (espB nucleotide sequences of strains CL559, CL617, CK379 and CL398, respectively) 


\section{INTRODUCTION}

Attaching and effacing Escherichia coli (AEEC) are an emerging cause of diarrhoea in humans and animals. These bacteria cause a characteristic attaching and effacing (AE) lesion in the gut mucosa because of the intimate bacterial adhesion to the enterocyte and effacement of the brush border microvilli (Moon et al., 1983). AEEC strains have been isolated from a number of animal species, including rabbits, pigs, cows, sheep, goats and dogs (Broes et al., 1988; Cantey \& Blake, 1977; Kuvda et al., 1996; Moxley \& Francis, 1986; Zhu et al., 1994). Human enteropathogenic E. coli (EPEC) and human enterohaemorrhagic E. coli (EHEC) cause AE lesions in the intestinal mucosa (reviewed by Frankel et al., 1998). EPEC were epidemiologically incriminated as a cause of sporadic and epidemic infantile diarrhoea in the 1940s and 1950s and have continued to be an important cause of infantile diarrhoea and mortality in developing countries (Nataro \& Kaper, 1998). EHEC cause diarrhoea or haemorrhagic colitis (HC) in humans, leading to a life-threatening complication termed haemolytic uraemic syndrome (HUS) (Nataro \& Kaper, 1998). EHEC strains are zoonotic foodborne pathogens, and cattle are the most important animal reservoir of these strains (Griffin \& Tauxe, 1991; Wells et al., 1991). AE lesions are the most significant feature of the pathogenesis of EPEC infections (Nataro \& Kaper, 1998). EHEC strains also produce Shiga toxins (Stxs), which are essential for the development of HC and HUS (Nataro \& Kaper, 1998). Two classes of AEEC strains have also been isolated from cattle: those which only produce AE lesions and those which produce Stxs in addition to AE lesions (Mainil et al., 1993; China et al., 1998, 1999b). Both classes of AEEC strains are frequently isolated from diarrhoeic calves and have been associated with enteric disease in neonatal calves (Fischer et al., 1994; Moxley \& Francis, 1986; Wieler et al., 1998). They are usually referred to as bovine EPEC and bovine EHEC by analogy with human strains. In rabbits, AEEC strains are well-established aetiological agents of diarrhoea, and are known as rabbit EPEC (REPEC) (reviewed by Milon et al., 1999). In addition to these groups of AEEC, other enteropathogenic bacteria, including Hafnia alvei, which has been isolated from children with diarrhoea, and Citrobacter rodentium, the causative agent of transmissible colonic hyperplasia in laboratory mice, cause AE lesions in the intestine (Albert et al., 1992; Shauer \& Falkow, 1993).

All the genes necessary for AE lesion formation by human EPEC are encoded in a pathogenicity island called the locus for enterocyte effacement (LEE) (McDaniel et al., 1995; McDaniel \& Kaper, 1997). The LEE is present in all the bacteria that induce AE lesions (McDaniel et al., 1995; Wieler et al., 1998). The complete sequences for the LEE of human EPEC strain E2348/69 and human EHEC O157:H7 strain EDL933 have been determined (Elliot et al., 1998; Perna et al., 1998). The LEE encodes a type III secretion system, a series of proteins secreted by this system called Esps (for EPEC secreted proteins), intimin, which mediates in- timate bacterial adhesion to epithelial cells, and Tir, a receptor for intimin which is translocated into host cells (reviewed by Frankel et al., 1998). The eae gene, encoding intimin, has been sequenced in a variety of $\mathrm{AE}$ bacteria including human EPEC and EHEC (Jerse et al., 1990; Yu \& Kaper, 1992; McGraw et al., 1999), AEEC strains isolated from a rabbit, a calf, a dog and a pig (Agin et al., 1996; An et al., 1997; China et al., 1999b), and C. rodentium and $H$. alvei (Frankel et al., 1994; Schauer \& Falkow, 1993). Comparison of the deduced amino acid sequences has revealed that intimins are highly conserved proteins at the $\mathrm{N}$-terminal region, but highly variable at their $\mathrm{C}$-termini. The differences in amino acid sequences at the C-termini are correlated with antigenic variation (Frankel et al., 1994). On the basis of antigenic variation, PCR analysis and sequencing, at least five subtypes of intimins have been identified: $\alpha, \beta, \gamma, \Delta$ and $\varepsilon$ (Agin \& Wolf, 1997; AduBobie et al., 1998; Oswald et al., 2000). It appears that specific intimin subtypes are associated with the distinct lineages of human EPEC and EHEC (Adu-Bobie et al., 1998).

The second gene that was identified in EPEC as necessary for induction of $\mathrm{AE}$ lesions was the espB gene (Donnenberg et al., 1993). Secretion of the EspB protein is essential for signal transduction in host cells and $\mathrm{AE}$ lesion formation (Foubister et al., 1994). However its function has not been elucidated. The espB gene has been sequenced in several strains, including human EPEC (Donnenberg et al., 1993), human and bovine EHEC (Ebel et al., 1996), and rabbit EPEC (Abe et al., 1997). Comparison of the deduced amino acid sequences has revealed that, like intimins, EspB are highly variable proteins. The variability in genes encoding proteins that interact directly with the host, in contrast to other LEEencoded proteins, which are highly conserved, suggests that these variable proteins are subject to selection for evasion of the host immune system (Frankel et al., 1998).

In small ruminants, AEEC strains and their possible association with diarrhoea in neonatal animals have not been studied, although AE lesions have been observed in these animals (Janke et al., 1989; Drolet et al., 1994; Duhamel et al., 1992). The aim of this study was to investigate the variability of eae and $\operatorname{esp} B$, two genes of the LEE directly involved in interactions with the host, in AEEC isolates from diarrhoeic lambs and goat kids. In addition, genetic relatedness of selected strains was investigated by PFGE.

\section{METHODS}

Bacterial strains. A total of 398 E. coli strains isolated from diarrhoeic lambs (246 strains) and goat kids (152 strains) were used in this study. These E. coli strains were part of our field strain laboratory collection and were isolated from different outbreaks of ovine and caprine neonatal diarrhoea in the central region of Spain. The strains were isolated from the faeces of diarrhoeic animals up to $21 \mathrm{~d}$ old; one strain per animal was selected. All strains have been examined for production of verotoxins (VT1 and VT2) and cytotoxic necrotizing factors (CNF1 and CNF2), and their serogroup 
determined as described previously (Blanco et al., 1996; Cid et al., 1996). Eight ovine strains and one caprine strain produced VT1, and two caprine strains produced CNF2 (see Table 2). Bacterial strains were maintained in semisolid nutrient broth (Difco) and plated out on blood agar medium (BioMérieux) as needed. The typable ovine and caprine strains belonged to 40 different serogroups; $25 \%$ of strains were untypable. The EPEC strains E2348/69 (O127:H6) and E2430/78 (O111:NM), the EHEC strain EDL933 (O157:H7) and the rabbit EPEC strain RDEC-1 (O15:NM) were used as prototype strains carrying eae and $e s p B$ gene subtypes.

Detection of AEEC strains by colony hybridization. The presence of eae gene sequences among E. coli field strains was determined by colony hybridization using the $1 \mathrm{kbp}$ SalI-KpnI fragment derived from the plasmid pCVD434 as the eae probe (Jerse et al., 1990). The DNA fragment was obtained by digestion, resolved by electrophoresis in $1 \%$ agarose gels and purified with the Qiaquick gel extraction kit (Qiagen). The DNA probe was labelled by random priming using $\left[\alpha^{32} \mathrm{P}\right] \mathrm{dCTP}$ and the random-primed DNA labelling kit (Amersham Life Science) according to the manufacturer's instructions. Bacterial strains were grown on Luria-Bertani (LB) broth overnight at $37^{\circ} \mathrm{C}$ and $2 \mu \mathrm{l}$ of each broth culture was inoculated onto LB agar and this further incubated at $37^{\circ} \mathrm{C}$ overnight. Colonies were transferred onto nylon membranes (Hybond-N, Amersham Life Science) and subjected to cell lysis, DNA denaturation and neutralization. DNA was fixed by UV cross-linking. Hybridizations were performed overnight at $65{ }^{\circ} \mathrm{C}$ in $7 \%$ SDS, $0.5 \mathrm{M}$ sodium phosphate $(\mathrm{pH}$ 7.2), $1 \mathrm{mM}$ EDTA. Membranes were washed for $20 \mathrm{~min}$ at $65^{\circ} \mathrm{C}$ in $2 \times \mathrm{SSC}(1 \times \mathrm{SSC}$ is $0.15 \mathrm{M} \mathrm{NaCl}$ plus $0.015 \mathrm{M}$ sodium citrate) $/ 0 \cdot 1 \%$ SDS and $20 \mathrm{~min}$ at $65^{\circ} \mathrm{C}$ in $0 \cdot 1 \times$ SSC $/ 0 \cdot 1 \%$ SDS, and autoradiographed.

PCR amplification and nucleotide sequencing of eae genes. Bacterial DNA samples for amplification were obtained with cetyltrimethylammonium bromide as described by Ausubel $e t$ al. (1991). PCR reactions were performed in a final volume of $100 \mu \mathrm{l}$ containing $1 \times \mathrm{PCR}$ buffer (Perkin Elmer), $0.2 \mathrm{mM}$ deoxynucleoside triphosphates, $1.5 \mathrm{mM} \mathrm{MgCl}_{2}, 0.5 \mu \mathrm{M}$ of each primer and $2.5 \mathrm{U}$ AmpliTaq Gold polymerase (Perkin Elmer). PCR conditions used for all primers were a first cycle of denaturation at $94^{\circ} \mathrm{C}$ for $10 \mathrm{~min}, 30$ cycles of denaturation at $94^{\circ} \mathrm{C}$ for $1 \mathrm{~min}$, annealing at $50^{\circ} \mathrm{C}$ for $1 \mathrm{~min}$ and extension at $72{ }^{\circ} \mathrm{C}$ for $3 \mathrm{~min}$, and a final extension at $72{ }^{\circ} \mathrm{C}$ for $10 \mathrm{~min}$.

PCR to amplify the $5^{\prime}$ region of the eae gene from field strains was performed with the forward primer AE9 (5'-ACG TTG CAG CAT GGG TAA CTC-3') previously described by Gannon et al. (1993) and the reverse consensus primer rEAE5 (5'-CGA AGT CTT ATC AGC CGT AAG T-3') complementary to bases 1685-1707 of the gene of strain E2348/69 (Jerse et al., 1990). This primer pair amplifies a $2.3 \mathrm{kbp}$ fragment comprising the $5^{\prime}$ end of the eae gene and $590 \mathrm{bp}$ upstream of the gene.

PCR products were analysed by electrophoresis in $1 \%$ agarose gels, recovered with the Qiaquick gel extraction kit (Qiagen) and characterized by restriction analysis with PstI (New England Biolabs). Purified PCR products obtained from two independent PCR reactions were ligated into the pMOSBlue vector and the plasmids generated used to transform competent $E$. coli strains using the pMOSBlue T-vector kit (Amersham Life Science). Transformants were selected on LB agar containing ampicillin $\left(100 \mu \mathrm{g} \mathrm{ml}^{-1}\right)$ and the presence of the appropriate fragment confirmed by PCR. DNA sequences of cloned PCR fragments were determined by automated sequencing using primers based on the previously determined sequence and a 373A DNA sequencer (Applied Biosystems). The sequences obtained were compared with eae gene sequences in the databases using the BLASTX program. The information generated in this manner was used to select reverse primers to amplify the $3^{\prime}$ region of eae genes. Reverse primers were based on the $3^{\prime}$ region of published eae gene sequences. These primers were combined with the forward primer $\mathrm{f} E A E-5$, which is complementary to the $\mathrm{r} E A E-5$ primer. PCR products obtained from two independent reactions were cloned and sequenced as described above. Finally, the entire genes were amplified using appropriate primers selected from those used to sequence the genes and sequences were confirmed by automated sequencing directly on purified PCR products. Sequences were compared with sequence databases using the BLASTX program. Multiple alignments of the sequences obtained and published eae sequences were performed with CLUSTAL (Higgins \& Sharp, 1988).

Detection of espB gene by Southern blot hybridization. Samples of bacterial DNA were digested with PstI and EcoRI (New England Biolabs); the restriction fragments were resolved by electrophoresis in $1 \%$ agarose gels and transferred onto nylon membranes (Hybond- $\mathrm{N}^{+}$, Amersham Life Science).

The DNA probe for detection of espB was generated by PCR amplification from EPEC reference strain E2348/69 (Donnenberg et al., 1993). A 930 bp fragment of espB was amplified with the $f e a e \mathrm{~B}$ and $r e a e \mathrm{~B}$ primers previously described by Beaudry et al. (1996) (Table 1). Bacterial DNA from strain E2348/69 was released by boiling in $500 \mu \mathrm{l}$ sterile water at $100{ }^{\circ} \mathrm{C}$ for $10 \mathrm{~min}$. The boiled suspension was centrifuged and $10 \mu \mathrm{l}$ of the supernatant used as template. The amplification reactions were performed in a final volume of $100 \mu \mathrm{l}$ containing $1 \times$ PCR buffer II (Perkin Elmer), $0 \cdot 2 \mathrm{mM}$ of each deoxynucleoside triphosphate, $1.5 \mathrm{mM} \mathrm{MgCl}_{2}, 0.5 \mu \mathrm{M}$ of each primer, $2.5 \mathrm{U}$ AmpliTaq Gold polymerase (Perkin Elmer) and $10 \mu \mathrm{l}$ of the DNA template. PCR reactions were carried out using an initial incubation at $94^{\circ} \mathrm{C}$ for $10 \mathrm{~min}$ followed by 30 cycles of denaturation at $94^{\circ} \mathrm{C}$ for $1 \mathrm{~min}$, annealing at $55^{\circ} \mathrm{C}$ for $1 \mathrm{~min}$ and elongation at $72{ }^{\circ} \mathrm{C}$ for $1 \mathrm{~min}$, and a final incubation at $72{ }^{\circ} \mathrm{C}$ for $5 \mathrm{~min}$. PCR products were separated by electrophoresis in $1 \%$ agarose gels, purified with the Qiaquick gel extraction kit (Qiagen) and labelled by randomprimed DNA synthesis in the presence of $\left[\alpha^{32} \mathrm{P}\right] \mathrm{dCTP}$ as described above. Southern blot hybridizations with the espB probe were performed as described above for colony hybridization with the eae probe.

PCR to amplify espB gene subtypes from eae-positive field strains and sequencing. Primers were designed on the basis of previously published nucleotide sequences of esp $B$ genes. DNA sequences were obtained from the GenBank database and aligned using CLUSTAL. DNA sequences of $e s p B$ genes used in this study included those of human EPEC strain E2348/69 (GeneBank accession A21555), human EHEC O157:H7 strain EDL933 (X96953, Y13068), rabbit EPEC strain RDEC-1 (ECU80796), rabbit EPEC strain B10 (AF054421), calf STEC strain 413/89-1 (X99670), dog EPEC strain 4221 (ECU65681) and swine AEEC strain 1390 (AF064683). Primers were selected on the basis of sequence identity, annealing temperature and size of predicted PCR products (Table 1). Primers feae $\mathrm{B}$ and reae $\mathrm{B}$, designed by Beaudry et al. (1996), were also used. Bacterial DNA was obtained by incubating cells suspended in sterile water at $100{ }^{\circ} \mathrm{C}$ for $10 \mathrm{~min}$. The suspension was centrifuged and the supernatant used as template. PCR reactions were carried out in a final volume of $50 \mu \mathrm{l}$, containing $10 \mu \mathrm{l}$ of the DNA template, $0.5 \mu \mathrm{M}$ of each of the 
Table 1. Primers used for $P C R$ espB gene typing and sequencing

\begin{tabular}{|c|c|c|c|c|c|}
\hline \multirow[t]{2}{*}{ Name } & \multirow[t]{2}{*}{ Position $†$} & \multirow[t]{2}{*}{ Orientation } & \multirow[t]{2}{*}{ Sequence $\left(5^{\prime}-3^{\prime}\right)$} & \multicolumn{2}{|c|}{ PCR product } \\
\hline & & & & Size $(b p)$ & espB subtype \\
\hline B1 & $241-257$ & Forward & GGCGTTTTTGAGAGCCA & - & - \\
\hline B2 & $499-484$ & Reverse & GATGCCTCCTCTGCGA & $260 \ddagger$ & $\operatorname{esp} B \gamma$ \\
\hline B3 & $686-668$ & Reverse & ATCTTATCTACTGCAGCCA & $435 \ddagger$ & $\operatorname{esp} B \beta$ \\
\hline ReaeB* & 939-920 & Reverse & CATGCGATTAATAAGGTCAG & $700 \neq$ & $\operatorname{esp} B \alpha$ \\
\hline FeaeB* & $9-28$ & Forward & TATCGATAATAACAATGCGG & $930 \$$ & $\operatorname{esp} B \alpha$ \\
\hline
\end{tabular}

*Primers described by Beaudry et al. (1996).

† Position numbers are from the nucleotide sequence of the espB gene of strain E2348/69 (GenBank accession number Z21555).

$\ddagger$ PCR product obtained in association with primer B1.

PCR product obtained in association with primer reaeB.

appropriate primers, $0.2 \mathrm{mM}$ of each deoxynucleotide triphosphate, $5 \mu \mathrm{l} \mathrm{PCR}$ buffer II (Perkin-Elmer), $3 \mu \mathrm{l} 25 \mathrm{mM}$ $\mathrm{MgCl}_{2}$ solution and $1.5 \mathrm{U}$ AmpliTaq Gold polymerase (Perkin-Elmer). PCR amplifications were performed with an initial denaturation at $94^{\circ} \mathrm{C}$ for $10 \mathrm{~min}, 30$ cycles of $94^{\circ} \mathrm{C}$ for $1 \mathrm{~min}, 50^{\circ} \mathrm{C}$ for $1 \mathrm{~min}$ and $72^{\circ} \mathrm{C}$ for $1 \mathrm{~min}$, and a final incubation at $72{ }^{\circ} \mathrm{C}$ for $10 \mathrm{~min}$. Twenty microlitres of each reaction mixture was analysed by electrophoresis in $1 \%$ agarose gels.

The nucleotide sequences of selected $\operatorname{es} p B$ PCR products were determined directly from purified PCR products. The sequences of both strands were determined using the amplification primers and an Applied Biosystems model 373 A automated DNA sequencer. Analysis and assembly of sequences were performed with the Chromas (1.43) program and searches for homologous sequences in the databases were done with the BLASTX program.

PFGE. Genomic DNA for contour-clamped homogeneous electric field electrophoresis (CHEF) was prepared in agarose plugs as described by Smith \& Cantor (1987). Genomic DNA of selected strains was digested with restriction enzymes Sfi or NotI (New England Biolabs) according to the manufacturer's instructions. Restriction fragments were separated in $1 \%$ agarose gels using a CHEF apparatus (LKB) with pulse time conditions varied depending on the size range of fragments to be resolved. A lambda ladder (New England Biolabs) was used as molecular size marker. The PFGE patterns were compared by the unweighted pair group method with arithmetic averages (UPGMA) clustering method using the Dice coefficient. Relationships between isolates were determined using the criteria of Tenover et al. (1996).

Rabbit ligated intestinal loop assay and demonstration of $A E$ lesions. The ability of bacterial strains to produce AE lesions was determined in the rabbit ligated intestinal loop assay (Moon et al., 1983). Bacteria were grown in Penassay broth (Difco) at $37^{\circ} \mathrm{C}$ overnight. They were washed once and resuspended in $10 \mathrm{mM}$ phosphate-buffered saline (PBS), $\mathrm{pH} 7 \cdot 4$, at a final concentration of approximately $1.5 \times 10^{8}$ c.f.u. $\mathrm{ml}^{-1}$. Three-month-old New Zealand White rabbits were used. One millilitre of bacterial suspension was inoculated into each ligated loop. After $18 \mathrm{~h}$, rabbits were killed by intravenous injection of sodium pentobarbital and tissue samples were taken for light and electron microscopic examination. Each strain was tested in at least two different animals.

\section{RESULTS}

\section{Prevalence of eae in ovine and caprine $E$. coli strains}

Colonies of 50 of the 398 strains, 23 ovine and 27 caprine, hybridized with the eae probe (Table 2). The 23 ovine eae-positive strains belonged to only five serogroups of the 39 serogroups analysed, or were untypable. The 27 caprine eae-positive strains belonged to three of the 19 serogroups analysed. All the ovine strains belonging to serogroups $\mathrm{O} 2, \mathrm{O} 26, \mathrm{O} 80$ and $\mathrm{O} 91$ and all the caprine strains belonging to serogroups O3, O153 and $\mathrm{O} 163$ were eae-positive, whereas only two of the seven ovine strains belonging to serogroup O4 were eaepositive (Table 2). None of the eae-positive strains were verotoxigenic, but two caprine eae-positive O153 strains produced CNF2.

\section{Analysis and sequencing of eae genes}

Since eae genes of ovine and caprine E. coli strains have not been described previously, we decided to amplify the highly conserved $5^{\prime}$ region of eae genes from field strains to analyse them further. All the strains that were positive by colony hybridization yielded products of $2.3 \mathrm{kbp}$ (Table 3). The PCR products were digested with PstI and the restriction patterns obtained were compared with the Pst I restriction map of the corresponding 5' region of eae nucleotide sequences of $\alpha$ intimin prototype strain E2348/69, $\beta$ intimin prototype strain RDEC-1 and $\gamma$ intimin prototype strain EDL933 (Fig. 1). Two different patterns were observed among $5^{\prime}$ eae regions of field strains. Pattern I, which was identical to the restriction pattern of the $5^{\prime}$ eae region of $\beta$ intimin prototype strain RDEC-1, was obtained from PCR products from 43 strains, and pattern II, identical to the restriction pattern of the $5^{\prime}$ eae region of $\alpha$ and $\gamma$ intimin prototype strains, was obtained from PCR products from seven of the ovine strains. A caprine strain, CK379, which yielded pattern I and an ovine strain, CL559, which yielded pattern II were selected for sequencing of the $5^{\prime}$ eae region. The DNA sequences of the $5^{\prime}$ regions of both strains were analysed and compared with published eae 
Table 2. Detection of the eae gene by colony blot hybridization among $E$. coli strains of different serogroups isolated from diarrhoeic lambs and goat kids

\begin{tabular}{|c|c|c|c|c|c|c|c|}
\hline $\begin{array}{l}\text { Source and } \\
\text { serogroup }\end{array}$ & $\begin{array}{l}\text { No. of } \\
\text { strains } \\
\text { tested }\end{array}$ & $\begin{array}{c}\text { No. of } \\
\text { eae- } \\
\text { positive } \\
\text { strains }\end{array}$ & $\begin{array}{l}\text { Toxin produced } \\
\text { (no. of strains) }\end{array}$ & $\begin{array}{l}\text { Source and } \\
\text { serogroup }\end{array}$ & $\begin{array}{l}\text { No. of } \\
\text { strains } \\
\text { tested }\end{array}$ & $\begin{array}{c}\text { No. of } \\
\text { eae- } \\
\text { positive } \\
\text { strains }\end{array}$ & $\begin{array}{c}\text { Toxin produced } \\
\text { (no. of strains) }\end{array}$ \\
\hline Ovine & 246 & 23 & & Caprine & 152 & 27 & \\
\hline $\mathrm{NT}^{*}$ & 41 & 4 & VT1 (4)† & NT & 30 & 0 & \\
\hline O1 & 3 & 0 & & O3 & 12 & 12 & \\
\hline $\mathrm{O} 2$ & 3 & 3 & & O8 & 14 & 0 & VT1 (1) \\
\hline O3 & 4 & 0 & & O9 & 20 & 0 & \\
\hline O4 & 7 & 2 & & O10 & 5 & 0 & \\
\hline O5 & 2 & 0 & & O11 & 12 & 0 & \\
\hline O6 & 6 & 0 & & O21 & 8 & 0 & \\
\hline O7 & 7 & 0 & & O43 & 1 & 0 & \\
\hline O8 & 27 & 0 & & O44 & 7 & 0 & \\
\hline O9 & 10 & 0 & & O62 & 3 & 0 & \\
\hline O11 & 35 & 0 & VT1 (1) & O77 & 4 & 0 & \\
\hline O18 & 3 & 0 & & O87 & 2 & 0 & \\
\hline O21 & 4 & 0 & & O91 & 1 & 0 & \\
\hline $\mathrm{O} 23$ & 8 & 0 & & O101 & 4 & 0 & \\
\hline O26 & 5 & 5 & & O103 & 6 & 0 & \\
\hline $\mathrm{O} 27$ & 3 & 0 & & O114 & 3 & 0 & \\
\hline O29 & 4 & 0 & & O116 & 5 & 0 & \\
\hline O33 & 1 & 0 & & O153 & 8 & 8 & CNF2 (2)‡ \\
\hline O35 & 1 & 0 & & O163 & 7 & 7 & \\
\hline O41 & 1 & 0 & & & & & \\
\hline O73 & 4 & 0 & & & & & \\
\hline O77 & 14 & 0 & & & & & \\
\hline O80 & 5 & 5 & & & & & \\
\hline O82 & 1 & 0 & & & & & \\
\hline O83 & 1 & 0 & & & & & \\
\hline O90 & 4 & 0 & & & & & \\
\hline O91 & 4 & 4 & & & & & \\
\hline O98 & 1 & 0 & & & & & \\
\hline O101 & 10 & 0 & & & & & \\
\hline O108 & 3 & 0 & & & & & \\
\hline O114 & 5 & 0 & & & & & \\
\hline O116 & 2 & 0 & & & & & \\
\hline O117 & 3 & 0 & VT1 (1) & & & & \\
\hline O132 & 1 & 0 & & & & & \\
\hline O138 & 3 & 0 & & & & & \\
\hline O147 & 1 & 0 & & & & & \\
\hline O161 & 6 & 0 & & & & & \\
\hline O166 & 2 & 0 & VT1 (2) & & & & \\
\hline O170 & 1 & 0 & & & & & \\
\hline
\end{tabular}

*NT, not typable.

† The strains producing VT1 were eae-negative by colony hybridization.

$\ddagger$ The strains producing CNF2 were eae-positive by colony hybridization.

sequences. The DNA sequence of the $5^{\prime}$ eae region of strain CK379 showed the highest identity $(99.6 \%)$ with that of rabbit strain RDEC-1 (Agin et al., 1996; GenBank accession no. ECU60002) and the DNA sequence of the $5^{\prime}$ eae region of strain CL559 showed the highest identity $(99 \%)$ with that of the human O111: NM EHEC strain 95NR1 (Voss et al., 1998; GenBank accession no.
AF025311). Analysis of the sequences also revealed the presence of an ORF of $471 \mathrm{bp}$ encoding a predicted protein of 156 amino acids. Comparison with sequence databases indicated that these ORFs were identical to the highly conserved orf $U$ gene of the LEE. The $471 \mathrm{bp}$ ORF of strains CK379 and CL559 showed $100 \%$ identity with orfU of strains RDEC-1 (Agin et al., 1996) and 
Table 3. Results of analysis of eae genes of $E$. coli strains isolated from diarrhoeic lambs and goat kids by PCR, intimin subtypes as determined by PCR, and Pstl restriction pattern of the 5 ' eae region amplified by PCR

\begin{tabular}{|c|c|c|c|c|c|}
\hline \multirow{3}{*}{$\begin{array}{l}\text { Source and } \\
\text { serogroup } \\
\text { (no of strains } \\
\text { analysed) }\end{array}$} & \multicolumn{3}{|c|}{ PCR amplification of } & \multirow{3}{*}{$\begin{array}{c}\text { Intimin } \\
\text { subtype (no. of } \\
\text { strains)* }\end{array}$} & \multirow{3}{*}{$\begin{array}{c}\text { PstI } \\
\text { restriction } \\
\text { pattern of } \\
5^{\prime} \text { eae } \\
\text { region }\end{array}$} \\
\hline & \multirow{2}{*}{$\begin{array}{c}5^{\prime} \text { eae region with } \\
\text { primers } \\
\mathrm{AE} 9+\mathrm{rEAE5}\end{array}$} & \multicolumn{2}{|c|}{$3^{\prime}$ eae region with primers } & & \\
\hline & & feae $5+$ END559 & feae $5+$ END379 & & \\
\hline \multicolumn{6}{|l|}{ Ovine } \\
\hline $\mathrm{NT}+(4)$ & + & - & + & $\beta(4)$ & I \\
\hline $\mathrm{O} 2(3)$ & + & + & - & $\gamma_{V} \ddagger(3)$ & II \\
\hline O4 (2) & + & - & + & $\beta(2)$ & I \\
\hline O26 (5) & + & - & + & $\beta(5)$ & I \\
\hline O80 (5) & + & - & + & $\beta(5)$ & I \\
\hline O91 (4) & + & + & - & $\gamma_{\mathrm{V}}(4)$ & II \\
\hline \multicolumn{6}{|l|}{ Caprine } \\
\hline O3 (12) & + & - & + & $\beta(12)$ & I \\
\hline O153 (8) & + & - & + & $\beta(8)$ & I \\
\hline O163 (7) & + & - & + & $\beta(7)$ & I \\
\hline
\end{tabular}

* All the strains belonging to one serogroup yielded identical results by PCR.

†NT, not typable.

$\neq \gamma$ variant defined in this study (see text).
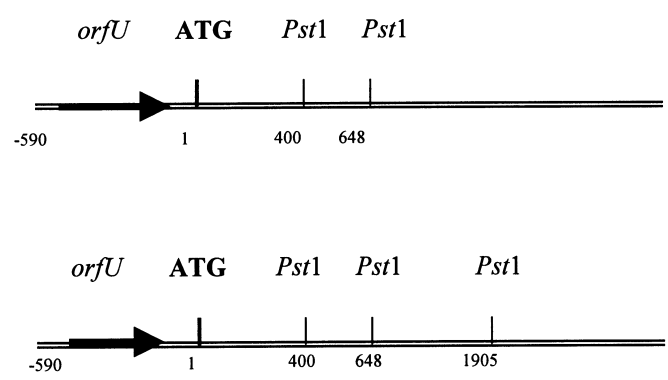

Pattern I: (strains) CK379 RDEC-1

Pattern II: (strains) CL559 E2348/69 EDL933

Fig. 1. Schematic representation of the $5^{\prime}$ region of the eae gene of ovine and caprine strains illustrating the two different Pstl patterns obtained, and the location of orfU (arrows) and the initiation codon (ATG) of eae. The 5' regions of the eae genes were obtained by PCR amplification of a $2.3 \mathrm{~kb}$ fragment with primers AE9 and EAE5.

95NR1 (Voss et al., 1998; GenBank accession no. AF025311), respectively.

On the basis of the DNA sequence similarity found, two reverse primers were designed to amplify the $3^{\prime}$ region of eae genes of strains CK379 and CL559. Primer END379 (5'-GTA CAA TAA AAA ATC CCG GAA A-3') was based on the eae region sequence of strain RDEC-1 (ECU 60002) $30 \mathrm{bp}$ downstream of the termination codon. Primer END559 (5'-AGA AGA AGA TAA TAA AGA AAC A-3') was based on the eae region sequence of strain 95NR1 (AF025311) 29 bp downstream of the termination codon. PCR products of approximately 1200 bp were amplified from CK379 and CL559 genomic DNA with primers $\mathrm{fEAE5}$ and END379 and primers
fEAE5 and END559, respectively. These products were cloned and sequenced and, as expected, showed the highest sequence identity with the $3^{\prime}$ eae regions of strains RDEC-1 and 95NR1, respectively. Finally, a common forward primer EAE1 (5'-AGG AAA TTA GTT CAA GCG ATA-3') starting at -108 and $-105 \mathrm{bp}$ relative to the initiation codon of eae genes of strains CK379 and CL559, respectively, was designed. This primer was combined with primers END379 and END559 to amplify the entire eae gene of strains CK379 and CL559. The PCR products obtained were sequenced and this confirmed the eae gene sequences of strains CK379 and CL559, as well as the high degree of sequence identity with those of strains RDEC-1 (99\%) and 95NR1 $(98 \%)$, respectively. The intimin C-terminal domains of strains CK379 and CL559 were also compared with those of published $\alpha, \beta, \gamma, \delta$ and $\varepsilon$ intimins of several prototype strains and intimin of human EHEC strain 95NR1 by multiple sequence alignment, and a phylogenetic tree was constructed from this alignment (Fig. 2 ). This analysis revealed that the intimin C-terminus of strain CK379 was nearly identical to that of $\beta$ intimins of rabbit EPEC strain RDEC-1 (Agin et al., 1996) and human O114:H2 EPEC strain ICC61 (Adu-Bobie et al., 1998). Thus, intimin of strain CK379 was classified as $\beta$ intimin. The intimin C-terminus of strain CL559 shared the greatest sequence identity $(96.5 \%)$ with that of strain 95NR1 (Voss et al., 1998), but also showed a high degree of identity with the C-termini of $\gamma$ intimins of human O157:H7 EHEC strains (76\%) and with the human EPEC strain O55:H7 DEC5d (75\%) (McGraw et al., 1999). On the basis of this identity, the intimin of strain CL559 was considered to be a variant of $\gamma$ intimin and termed $\gamma_{\mathrm{V}}$. 


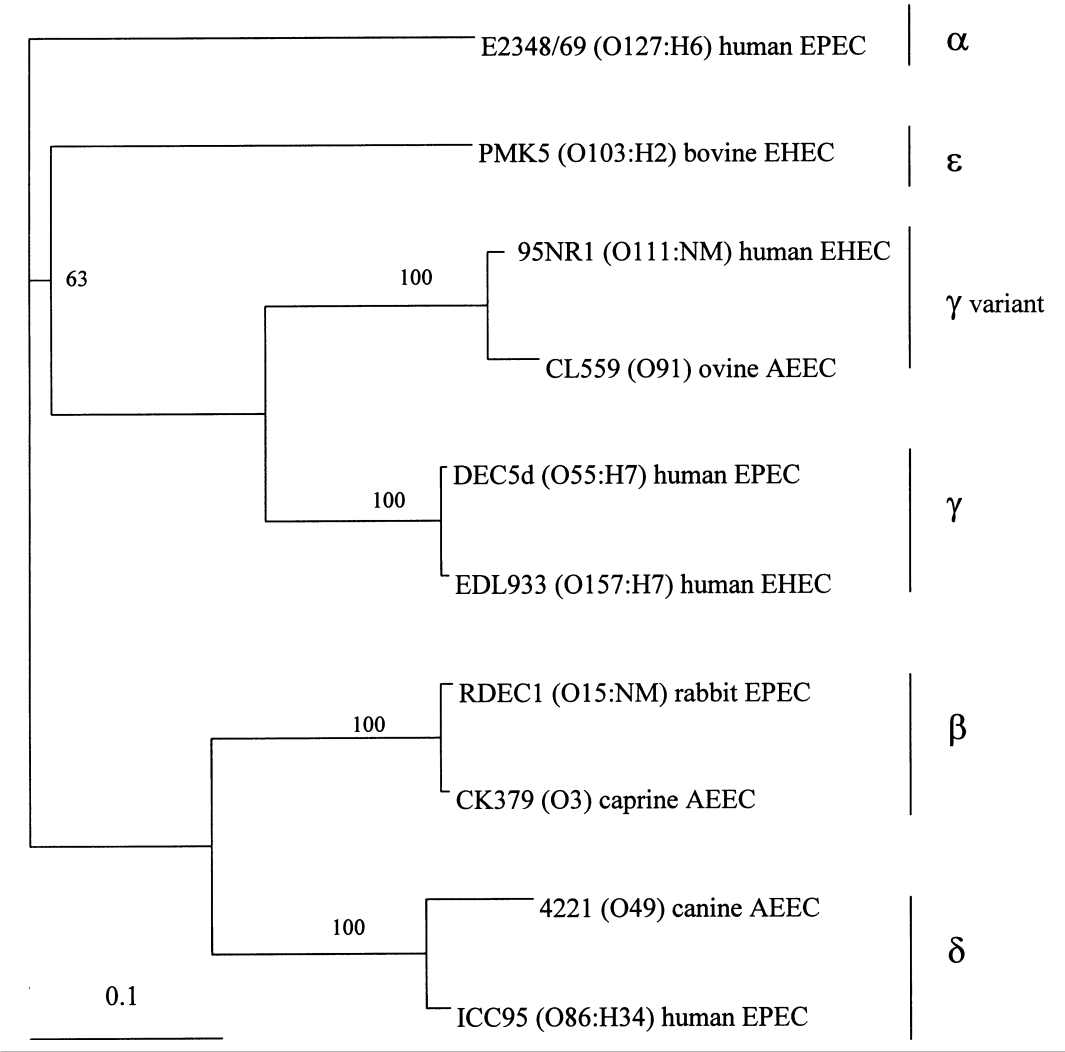

\begin{abstract}
Fig. 2. Phylogenetic tree based on CLUSTAL $W$ multiple sequence alignment of the amino acid sequences of the C-termini of intimins from caprine strain CK379 (GenBank accession no. AF253560) and ovine strain CL559 (AF253561) with those of published intimin subtypes starting from the conserved and universal amino acid sequence ASITEIKA. GenBank accession numbers of the intimin subtypes were Z11541 (strain EDL933), AF081184 (strain DEC5d), AF025311 strain (95NR1), AF116899 (strain PMK5), AF022236 (strain E2348/69), Y13112 (strain ICC95), U66102 (strain 4221) and U59503 (strain RDEC-1). The percentages of 2000 bootstrap replicates supporting each cluster are shown along the branches. Phylogenetic analysis was performed using the neighbour-joining method as implemented in CLUSTAL W.
\end{abstract}

The primer pairs fEAE5 + END379 and $\mathrm{fEAE5+}$ END559 were then used to investigate by PCR the prevalence of the $\beta$ and $\gamma_{\mathrm{V}}$ intimin genes in the ovine and caprine eae-positive strains detected in this study. The intimin $\beta$ gene was found in 43 strains, including CK379, and the intimin $\gamma_{\mathrm{V}}$ gene was found in seven strains, including CL559. All the strains with $\gamma_{V}$ intimin yielded the same Pst I restriction pattern from the $5^{\prime}$ eae region as strain CL559 (Table 3).

\section{Identification of espB genes and sequencing}

To identify espB genes of ovine and caprine $e a e$-positive strains, genomic DNAs were analysed by Southern blot hybridization with an $e s p B$ probe consisting of a $930 \mathrm{bp}$ PCR fragment of the esp $B$ gene of EPEC prototype strain E2348/69, which comprised nearly the entire espB gene. Only seven strains, all of ovine origin, hybridized with this probe (Table 4) even under hybridization conditions of low stringency. The presence of an esp $B$ gene similar to the $e s p B$ of strain E2348/69 correlated with the presence of an eae gene encoding intimin subtype $\gamma_{\mathrm{V}}$. Strains with an eae gene encoding the $\beta$ intimin subtype were not detected by the probe (Table 4). Two of the espB-positive strains (CL559 of serogroup O91 and CL617 of serogroup O2) were selected for determining the extent of the similarity of their espB with that of human EPEC strain E2348/69. The nucleotide sequences of the $930 \mathrm{bp}$ fragments generated by PCR from strains CL559 and CL617 were identical to each other, and had $95 \%$ identity with the corresponding fragment of the espB gene of strain E2348/69 (Donnenberg et al., 1993).
To detect other $e s p B$ types among the eae-positive, $e s p B$ probe-negative ovine and caprine strains, a PCR test was developed. Examination of published DNA sequences of espB genes by multiple alignment revealed that there were at least three subtypes of esp $B$ genes. One type included the espB genes of the human prototype EPEC strain E2348/69 (Donnenberg et al., 1993) and the canine strain 4221 (ECU65681). A second type was represented by the espB gene of the human EHEC strain EDL933 (Ebel et al., 1996). The third type was represented by the $\operatorname{esp} B$ gene of the rabbit EPEC strain RDEC-1 (Abe et al., 1997); this type also included the $e s p B$ genes of the rabbit EPEC strain B10 (AF054421), the calf STEC strain 413/89-1 (Ebel et al., 1996) and the swine AEEC strain 1390 (AF064683). We designated the $e s p B$ subtypes of prototype strains E2348/69, RDEC-1 and EDL933 as $e s p B \alpha, e s p B \beta$ and $e s p B \gamma$, respectively, by analogy with the designations of the intimin types of these prototype strains. This nomenclature has also been proposed by China et al. (1999a). Primers were designed on the basis of the published nucleotide sequences of $\operatorname{esp} B$ genes. Reverse specific PCR primers for $e s p B \beta$ and $e s p B \gamma$ subtypes were designed based on regions of low identity between subtypes, and the forward consensus primer B1 was based on a highly conserved region. Primer reaeB (Beaudry et al., 1996) was used as reverse primer for the esp $B \alpha$ subtype. The specificity of these PCR primers for esp $B$ gene subtypes was tested by using prototype strains for each subtype in three independent PCR assays (Table 4).

The results of the PCR assays showed that each primer 
Table 4. Results of PCR and Southern blot hybridization typing of espB gene and correlation with intimin subtype among eae $e^{+}$ovine and caprine $E$. coli strains

\begin{tabular}{|c|c|c|c|c|c|c|}
\hline & \multirow{3}{*}{$\begin{array}{l}\text { Intimin } \\
\text { type* }\end{array}$} & \multicolumn{4}{|c|}{ PCR typing of $e s p B$ genes } & \multirow{3}{*}{$\begin{array}{c}\text { Southern blo } \\
\text { hybridization } \\
\text { with probe } \\
\text { esp } B \neq\end{array}$} \\
\hline & & \multicolumn{3}{|c|}{ Amplification with primer pair } & \multirow{2}{*}{$\begin{array}{l}\text { Type (no. of } \\
\text { strains } \dagger \text { ) }\end{array}$} & \\
\hline & & $(\mathrm{B} 1+\mathrm{reae} \mathrm{B})$ & $(\mathrm{B} 1+\mathrm{B} 3)$ & $(\mathrm{B} 1+\mathrm{B} 2)$ & & \\
\hline \multicolumn{7}{|c|}{ Reference strains for esp $B$ gene typing $\mathbb{S}$} \\
\hline $\mathrm{E} 2348 / 69(\mathrm{O} 127: \mathrm{H} 6, \operatorname{esp} B \alpha)$ & $\alpha$ & + & - & - & $\alpha$ & + \\
\hline RDEC1 (O15: NM, espB $\beta$ ) & $\beta$ & - & + & - & $\beta$ & ND \\
\hline $\mathrm{E} 2430 / 78(\mathrm{O} 111: \mathrm{NM}$ espB $\beta)$ & $\beta$ & - & + & - & $\beta$ & ND \\
\hline EDL933 (O157: H7,espB $\gamma)$ & $\gamma$ & - & - & + & $\gamma$ & ND \\
\hline CL559 (O2, espB $\alpha) 9$ & $\gamma_{\mathrm{V}}$ & + & - & - & $\alpha$ & + \\
\hline CL617 (O91, espB $\alpha)$ g & $\gamma_{\mathrm{v}}$ & + & - & - & $\alpha$ & + \\
\hline \multicolumn{7}{|c|}{ Source and serogroup (no. of strains) } \\
\hline \multicolumn{7}{|c|}{ Ovine strains } \\
\hline NT (4) & $\beta$ & - & + & - & $\beta(4)$ & $-(4)$ \\
\hline $\mathrm{O} 2(2)$ & $\gamma_{\mathrm{V}}$ & + & - & - & $\alpha(2)$ & $+(2)$ \\
\hline O4 (2) & $\beta$ & - & + & - & $\beta(2)$ & $-(2)$ \\
\hline O26 (5) & $\beta$ & - & + & - & $\beta(5)$ & $-(5)$ \\
\hline O80 (5) & $\beta$ & - & + & - & $\beta(5)$ & $-(5)$ \\
\hline O91 (3) & $\gamma_{\mathrm{V}}$ & + & - & - & $\alpha(3)$ & $+(3)$ \\
\hline \multicolumn{7}{|l|}{ Caprine strains } \\
\hline O3 (12) & $\beta$ & - & + & - & $\beta(12)$ & $-(12)$ \\
\hline O153 (8) & $\beta$ & - & + & - & $\beta(8)$ & $-(8)$ \\
\hline O163 (7) & $\beta$ & - & + & - & $\beta(7)$ & $-(7)$ \\
\hline
\end{tabular}

*Intimin types of reference strains have been published previously (see text); intimin types of ovine and caprine strains were determined in this study (see Table 3).

† All the strains belonging to one serogroup yielded identical results by PCR.

$\ddagger$ The $\operatorname{esp} B$ probe was a $930 \mathrm{bp}$ fragment of the espB gene of human EPEC strain E2348/69 obtained by PCR. ND, Not done.

$\mathbb{S}$ The $e s p B$ genes of the prototype strains E2348/69, RDEC1 and EDL933 have been previously published and they were designated $e s p B \alpha$, $e s p B \beta$ and $e s p B \gamma$ subtype, respectively, in this study (see text).

g The espB subtypes of the ovine strains CL559 and CL617 were determined by sequencing and the espB subtype of strain E2430/78 was determined by PCR typing.

pair amplified a specific PCR product from the corresponding prototype strain and did not amplify any PCR product from strains with a heterologous esp $B$ gene subtype. EPEC strain E2430/78 (serotype O111:NM), which has been shown to posses $\beta$ intimin (Agin \& Wolf, 1997), and strains CL617 and CL559 (this study), which harbour espB genes homologous to that of strain E2348/69, were also included. Strain E2430/78 yielded the expected espB $\beta$ product with primers $\mathrm{B} 1+\mathrm{B} 3$. Strains CL559 and CL617 yielded product exclusively with the $\mathrm{B} 1+\mathrm{reae} \mathrm{B}$ primer pair, corresponding to an $e s p B \alpha$ gene subtype. The remaining eae-positive ovine and caprine strains were also analysed for esp $B$ subtype by PCR in three independent assays with each primer pair. The PCR results (Table 4) showed that all the strains that were negative by Southern hybridization with the esp $B$ probe produced a specific PCR product of the expected size with primer pair B1 $+\mathrm{B} 3$, corresponding to the $e s p B \beta$ gene subtype. The presence in these strains of an $e s p B$ gene homologous to that of strain RDEC-1 was confirmed by sequencing the PCR products from strains CK379 and CL398. Nucleotide sequences of the $\operatorname{esp} B$ genes of both strains had $100 \%$ identity with the corresponding DNA sequence of the espB gene of strain RDEC-1 (Abe et al., 1997).

\section{PFGE analysis of AEEC strains}

Six ovine (one of each identified serogroup and one untypable) and six caprine (two of each identified serogroup) eae-positive strains were selected for PFGE analysis (Fig. 3). The selected strains were epidemiologically unrelated, as they were collected in different years from different animals and different farms. All these selected strains induced typical AE lesions in the rabbit ligated ileal loop assay. The ovine and caprine strains adhered closely to ileal enterocytes and this adhesion was characterized by microvillus effacement and the induction of cup-like structures underneath adhering bacteria (Fig. 4).

The profiles of chromosomal DNA fragments generated using $S f i$ were compared in these representative strains. 


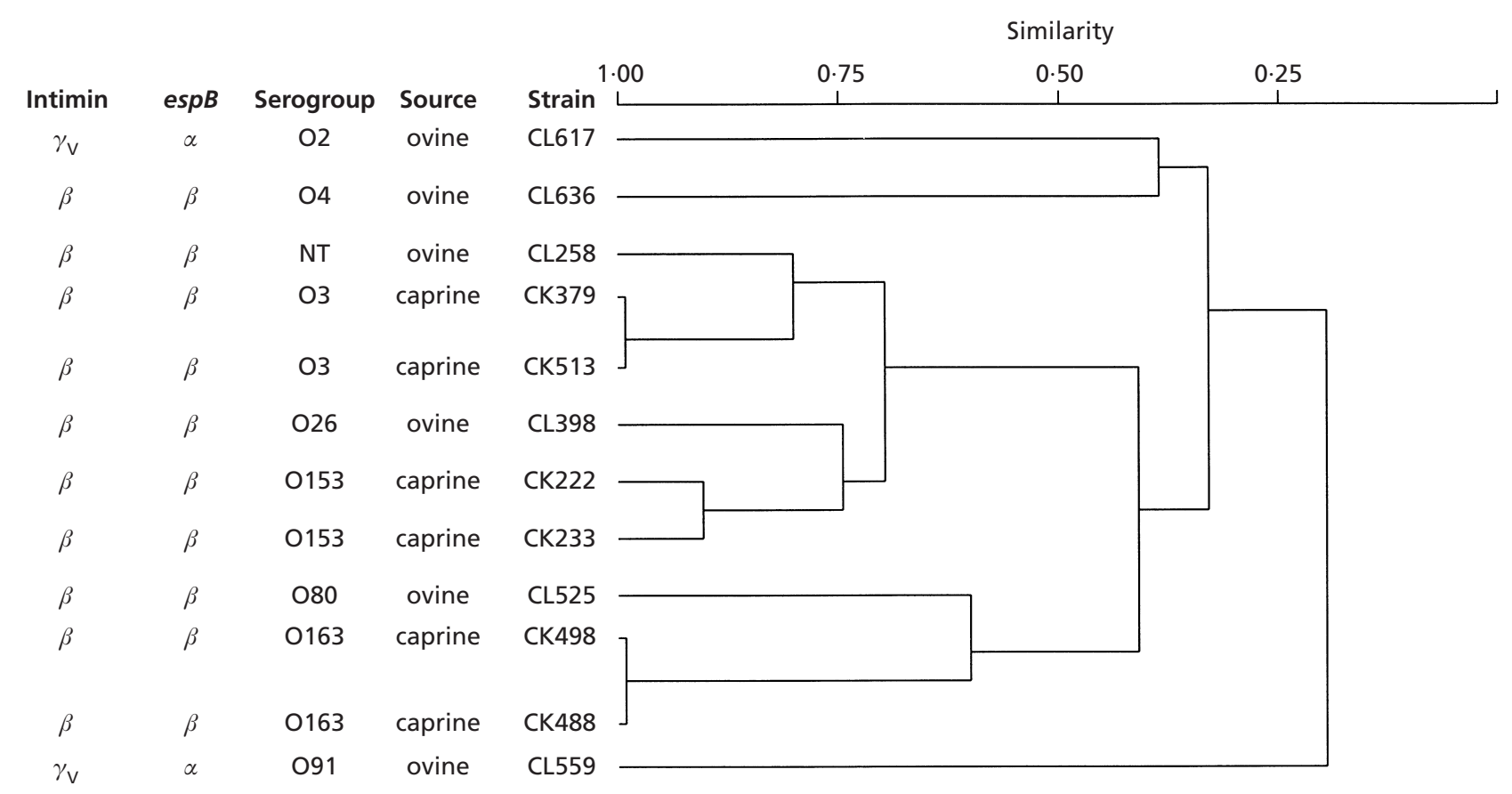

Fig. 3. Dendrogram illustrating the relatedness of $A E E C$ strains isolated from diarrhoeic lambs and goat kids and the serogroup, intimin and espB gene subtypes of strains. All these strains were shown to produce $A E$ lesions in the rabbit ligated intestinal loop assay (Moon et al., 1983). The tree was constructed by applying the unweighted pair-group method with arithmetic means to a matrix resulting from comparison of Sfil PFGE patterns.
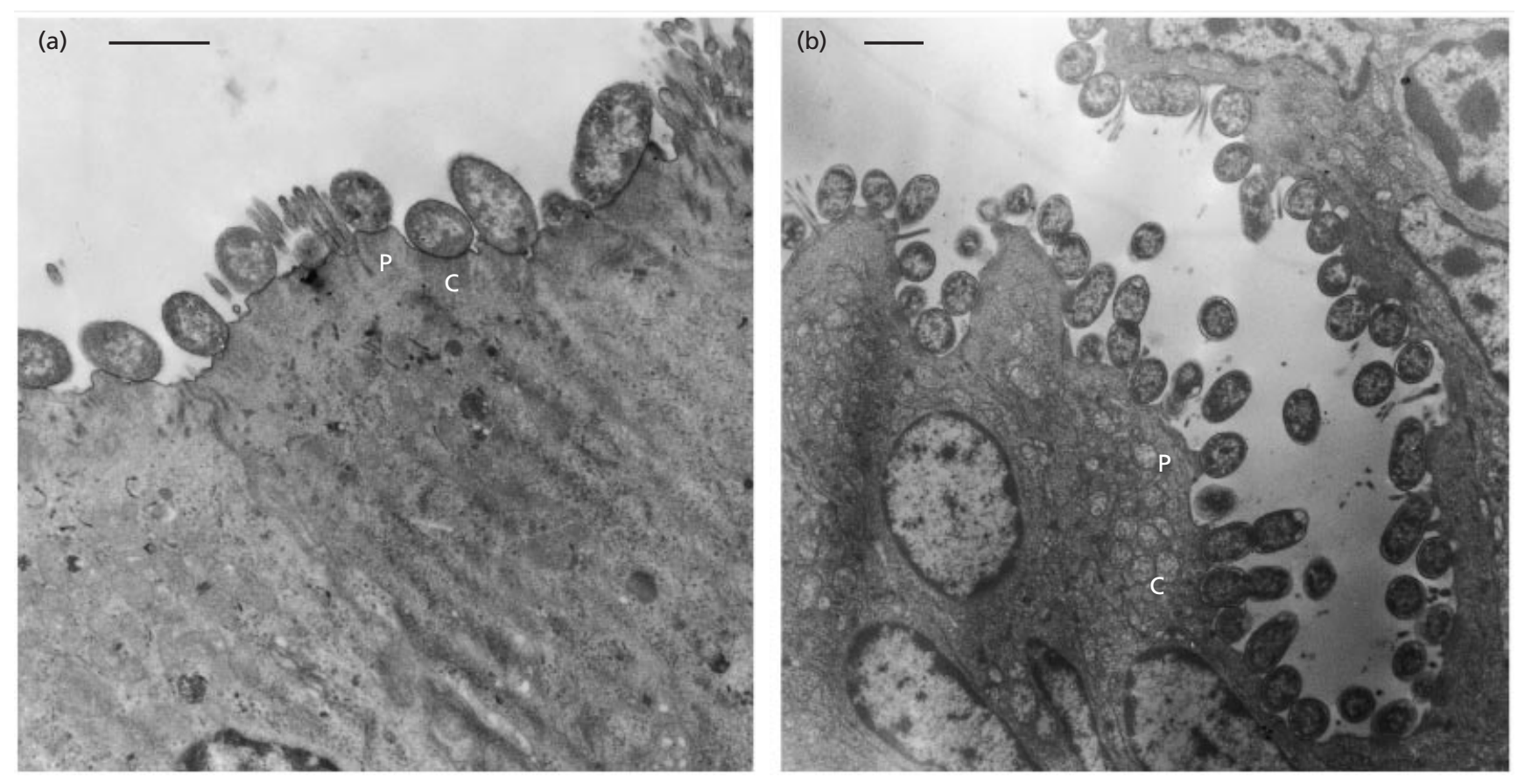

Fig. 4. Transmission electron microscopy of rabbit ligated intestinal loops inoculated with the ovine strain CL525 (a) and the caprine strain CK379 (b). Strains adhered to enterocytes and induced typical AE lesions characterized by an intimate attachment of bacteria to the enterocyte surface on pedestal structures (P) or cup-like structures (C) and associated with a destruction of microvilli. Samples were analysed $18 \mathrm{~h}$ after infection. Bars, $1 \cdot 1 \mu \mathrm{m}$. 
Although a different PFGE pattern was observed for each strain, Sfil-digested genomic DNA of caprine strains belonging to the same serogroup had fewer than three differing bands, and they were considered closely related according to the criteria of Tenover et al. (1996). This finding was confirmed using the restriction enzyme NotI. The PFGE profile of the untypable ovine strain CL258 had fewer than six differing bands when compared to the two serogroup O3 caprine strains (CK379 and CK513), suggesting that they may be related strains. A dendrogram was constructed to show the degree of relatedness between AEEC strains based on SfiI PFGE patterns using the Dice coefficient and UPGMA clustering. A group of six strains formed a cluster with similarity levels higher than $71 \%$ (Fig. 3). This group included the serogroup O3 and O153 caprine strains and the untypable and serogroup O26 ovine strains. The two serogroup O163 caprine strains were more than $97 \%$ similar and formed a group with similarity levels higher than $59.4 \%$ with the serogroup O80 ovine strains. All but one of the strains with $\beta$ intimin and $e s p B \beta$ gene subtypes formed a group with similarity levels greater than $40 \%$. The exception was the ovine serogroup O4 strain (Fig. 3). The two strains with the $\gamma_{\mathrm{V}}$ intimin and $e s p B \alpha$ gene subtypes showed the greatest genomic divergence (Fig. 3).

\section{DISCUSSION}

Two intimin subtypes were identified by analysis of eae genes in the ovine and caprine E. coli strains analysed in this study. Most of the eae-positive strains $(43 / 50)$ had $\beta$ intimin genes. This subtype seems to be the most widespread intimin subtype among human and animal AEEC strains; it has been found in human EPEC and EHEC strains, bovine EPEC and EHEC strains, rabbit EPEC strains, and AEEC strains of pig, dog and bird origin (Agin \& Wolf, 1997; Adu-Bobie et al., 1998; China et al., 1999b; McGraw et al., 1999; Oswald et al., 2000), and, in our study, in ovine and caprine AEEC strains. Intimin $\beta$ is almost identical in human EPEC and EHEC, rabbit EPEC, swine AEEC and bovine EHEC strains (Agin \& Wolf, 1997; China et al., 1999b). The amino acid sequence deduced from the eae gene of the caprine strain CK379 was also nearly identical to those of previously reported $\beta$ intimins.

The other intimin subtype detected in seven of the ovine AEEC strains studied was classified as a variant of $\gamma$ intimin (termed $\gamma_{V}$ ) on the basis of the identity of the deduced amino acid sequence of its C-terminal domain with those of previously published $\gamma$ intimin sequences. Intimin $\gamma$ is present in EHEC strains of clone 1 (serotypes O157:H7 and O157:H-) and the atypical EPEC clone (serotype O55:H-) from which O157:H7 EHEC strains are believed to have evolved (Whitman et al., 1993). The $\gamma$ intimins of these strains are virtually identical, supporting the hypothesis that they belong to a single clonal lineage (McGraw et al., 1999). The C-terminus of the $\gamma_{\mathrm{V}}$ intimin of the ovine strain CL559 had 75-76\% sequence identity with $\gamma$ intimin of EHEC clone 1
(McGraw et al., 1999), and $96 \%$ identity with intimin of the human O111: H-EHEC strain 95NR1 isolated from a patient with HUS and belonging to EHEC clone 2 (Voss et al., 1998). It is possible that these differences in amino acid sequence in the cell-binding domain represent antigenic variations, as Voss et al. (1998) found that serum from a HUS patient infected only with a serotype O111:H- EHEC strain reacted with intimin from an O111 EPEC strain, but not with that of an EHEC strain of clone 1. Recently, Oswald et al. (2000) detected intimin $\gamma$ in human EHEC strains of clone 2 (serotypes $\mathrm{O} 111: \mathrm{H}-$ and $\mathrm{O} 111: \mathrm{H} 8$ ), and in human EPEC strains of serotypes O127:H40, O128:H8 and O128: $\mathrm{H}-$ using PCR analysis. On the basis of the Pst restriction patterns of PCR products derived from the intimin gene, these authors differentiated two subtypes of $\gamma$ intimin, the first $(\gamma 1)$ shared by the EHEC strains of clone 1 , and the second $(\gamma 2)$ represented by EHEC O111 and EPEC O127:H40 and O128:H8 (Oswald et al., 2000). The intimin $\gamma 2$ detected by Oswald et al. (2000) in EHEC strains of clone 2 probably corresponds to the $\gamma_{\mathrm{V}}$ intimin identified in human EHEC strain 95NR1 by Voss et al. (1998) and in the CL559 ovine strain in our study. The two subtypes of $\gamma$ intimin may correspond to distinct clonal lineages of E. coli.

In this study, we developed a PCR test to identify the three different $e s p B$ gene subtypes detected by analysis of esp $B$ published sequences $(e s p B \alpha, e s p B \beta$ and $e s p B \gamma)$. Two types of $e s p B$ gene were found among ovine and caprine strains by PCR, espB $\alpha$ and $e s p B \beta$. Using a multiplex PCR assay, China et al. (1999a) also detected these two espB gene subtypes in bovine AEEC strains. Sequencing of PCR products from two selected strains with espB $\alpha$ (CL559 and CL617) and two with espB $\beta$ (CK379 and CL398) confirmed the espB gene classification using the PCR assay. Only the ovine strains with an $e s p B \alpha$ gene hybridized with the $\operatorname{esp} B$ probe derived from the espB gene of the human EPEC strain E2348/69. Previous studies have found that most AEEC strains isolated from diarrhoeic calves did not hybridize with the same $e s p B$ probe as used in our study (Wieler $e t$ al., 1998; China et al., 1998). The PCR test developed in our study was found to be highly specific, and it will be useful for identification of $e s p B$ gene subtypes in AEEC strains isolated from animals and humans.

In the strains studied, we found a close correlation between the intimin $\beta$ type and the espB $\beta$ gene subtype. It has been shown that the strain RDEC- 1 and the bovine EHEC strain 413-89-1 possessed identical espB genes (Ebel et al., 1996; Abe et al., 1997). Analysis by multiple sequence alignment of published espB gene sequences revealed that other rabbit EPEC strains, and the swine strain 1390, also possessed esp $B$ genes identical to that of RDEC-1, and all of these strains contain $\beta$ intimin genes. Therefore, there seems to be a correlation between $\beta$ intimin and $e s p B \beta$ subtype in AEEC strains of different origins. In addition to the eae and esp $B$ genes, the orfU gene of strain CK379 was also characterized, and it was identical to that of the prototype rabbit EPEC strain RDEC-1 (Abe et al., 1997). Since eae and espB are 
among the most variable genes of the LEE (Elliot et al., 1998; Perna et al., 1998), it is possible that the entire LEE of strain CK379 was identical to that of RDEC-1.

The ovine strains with $\gamma_{\mathrm{V}}$ intimin possessed an $e s p B$ gene subtype $(e s p B \alpha)$ different from the espB $\gamma$ detected in the EHEC clone 1 prototype strain EDL933 possessing $\gamma$ intimin. The espB genes of EHEC clone 2 or animal AEEC strains producing $\gamma$ intimin have not yet been sequenced, so it is uncertain whether EHEC clone 2 strains possess an $e s p B$ similar to the espB $\alpha$ defined in this study. However, the results of China et al. (1999a) suggest that the association between intimin and esp $B$ gene subtypes described in this study is also present in bovine AEEC and in human EHEC strains. Using a multiplex PCR assay, these authors detected three different combinations: $\beta$ intimin with $e s p B \beta, \gamma$ intimin with $\operatorname{esp} B \alpha$, and $\gamma$ intimin with $e s p B \gamma$. The last combination was only detected in O157:H7 EHEC strains of clone 1 , whereas the combination $\gamma$ intimin/esp $B \alpha$ was present in human EHEC strains of serogroup O111 and in bovine AEEC strains of different serogroups. It is possible that at least some of these strains with the $e s p B \alpha$ gene subtype possess the $\gamma_{\mathrm{V}}$ intimin rather than the $\gamma$ intimin since the primers used for amplification of $\gamma$ intimin by China et al. (1999a) do not allow distinction between $\gamma$ and $\gamma_{\mathrm{v}}$ intimin.

The ovine and caprine AEEC strains belonged to eight different serogroups (O2, O4, O26, O80, O91, O3, O153 and $\mathrm{O} 163$ ) or were untypable. It has been established that many serotypes of $E$. coli are genetically heterogeneous and, thus, the classification of strains based solely on $\mathrm{O}: \mathrm{H}$ serotyping is not always indicative of genetic relatedness (Whittman et al., 1993). PFGE typing combined with genetic analysis of virulence determinants has been shown to be useful for evaluation of genetic relatedness of pathogenic E. coli strains (Arbeit et al., 1990; Rios et al., 1999). In this study, PFGE typing showed that two strains with $\gamma_{\mathrm{V}}$ intimin and $\operatorname{esp} B \alpha$ genes were genetically more distant than the strains with $\beta$ intimin and espB $\beta$ genes (Fig. 3). Among the latter, although a high degree of diversity was also found, a group of six (four caprine and two ovine) strains formed a cluster with $71 \%$ or greater similarity and, according to the criteria of Tenover et al. (1996), three of these epidemiologically unrelated isolates (the ovine CL258 and the caprine CK379 and CK513 strains) are possibly related genetically. Moreover, caprine strains with the $\beta$ intimin and $e s p B \beta$ genes belonging to the same serogroup were also closely related, suggesting that they evolved from a common ancestor containing the LEE.

In cattle, both EPEC and EHEC strains are frequently isolated from diarrhoeic calves (Mainil et al., 1993; China et al., 1998; Wieler et al., 1998) and both types of strains have been shown to be pathogenic for neonatal calves (Moxley \& Francis, 1986; Fischer et al., 1994). In contrast, the pathogenicity of AEEC strains for small ruminants has not been investigated, although the occurrence of $\mathrm{AE}$ lesions in these animals has been reported (Janke et al., 1989; Duhamel et al., 1992; Drolet et al., 1994). AEEC strains isolated from diarrhoeic lambs and kids seem to be different from those isolated from diarrhoeic calves. None of the ovine and caprine eae-positive E. coli strains analysed in this study produced Stxs, and we have previously found that production of Stxs is not a common characteristic of $E$. coli strains isolated from diarrhoeic lambs and goat kids (Blanco et al., 1996; Cid et al., 1996).

Most of the ovine and caprine AEEC strains characterized in this study possessed the $\beta$ intimin gene. This intimin subtype is the most frequent subtype among EPEC strains isolated from diarrhoeic calves (China et al., 1999b), and it is also characteristic of rabbit EPEC (Agin \& Wolf, 1997; Adu-Bobie et al., 1998). Ovine and caprine strains with $\beta$ intimin were able to induce $\mathrm{AE}$ lesions in the rabbit ligated ileal loop model and they did not produce Stxs. Thus, these ovine and caprine AEEC strains should be classified as EPEC. It is possible that some of these strains, especially those of serogroup O26, which has been shown to be associated with enteric disease in calves and humans (China et al., 1999b; Mainil et al., 1993; Nataro \& Kaper, 1998), are pathogenic for lambs and kids. The association of the ovine AEEC strains possessing intimin $\gamma_{\mathrm{V}}$ with neonatal diarrhoea appears less likely. The isolation rate from diarrhoeic lambs is low, and it has been shown that intimin $\gamma$ is more frequent in EPEC strains isolated from healthy cattle than in EPEC isolated from diarrhoeic calves (China et al., 1999b). Intimin $\gamma$ is characteristic of human EHEC strains, which cause HC and HUS (Adu-Bobie et al. 1998; MGraw et al., 1999), and adult sheep are reservoirs of strains pathogenic for humans (Beutin et al., 1996; Kuvda et al., 1996). Although lambs could also be a reservoir of strains pathogenic for humans, the AEEC with the $\gamma_{V}$ intimin subtype did not produce Stxs. We found that these strains possessed a $\gamma_{\mathrm{V}}$ intimin, which differed from $\gamma$ intimin of the human O157:H7 EHEC. This $\gamma_{\mathrm{V}}$ intimin was present in the human O111:H- EHEC strain 95NR1 isolated from patients with enteric disease or HUS in an outbreak of disease caused by contaminated fermented sausage (Voss et al., 1998). It is possible that the ovine AEEC strains with $\gamma_{\mathrm{V}}$ intimin characterized in this study are normal inhabitants of the gut of sheep. Further studies to investigate the distribution of intimin subtypes among E. coli strains isolated from diarrhoeic and healthy small ruminants, as well as experimental studies of pathogenicity in lambs and kids, are needed to establish the possible role of AEEC strains in neonatal diarrhoea of small ruminants.

\section{ACKNOWLEDGEMENTS}

This study was supported by the Comisión Interministerial de Ciencia y Tecnología (grant AGF 95-0834)

\section{REFERENCES}

Abe, A., Kenny, B., Stein, M. \& Finlay, B. B. (1997). Characterization of two virulence proteins secreted by rabbit enteropathogenic Escherichia coli, EspA and EspB, whose maximal expression is sensitive to host body temperature. Infect Immun $\mathbf{6 5}, 3547-3555$. 
Adu-Bobie, J., Frankel, G., Bain, C., Goncalves, A. G., Trabulsi, L. R., Douce, G., Knutton, S. \& Dougan, G. (1998). Detection of intimins alpha, beta, gamma, and delta, four intimin derivatives expressed by attaching and effacing microbial pathogens. J Clin Microbiol 36, 662-668.

Agin, T. S. \& Wolf, M. K. (1997). Identification of a family of intimins common to Escherichia coli causing attaching-effacing lesions in rabbits, humans, and swine. Infect Immun 65, 320-326.

Agin, T. S., Cantey, J. R., Boedeker, E. C. \& Wolf, M. K. (1996). Characterization of the eaeA gene from rabbit enteropathogenic Escherichia coli strain RDEC-1 and comparison to other eaeA genes from bacteria that cause attaching-effacing lesions. FEMS Microbiol Lett 144, 249-258.

Albert, M. J., Faruque, S. M., Ansaruzzaman, M., Islam, M. M., Haider, K., Alam, L., Kabir, I. \& Robins-Browne, R. (1992). Sharing of virulence-associated properties at the phenotypic and genetic levels between enteropathogenic Escherichia coli and Hafnia alvei. J Med Microbiol 37, 310-314.

An, H., Fairbrother, J. M., Dubreuil, J. D. \& Harel, J. (1997). Cloning and characterization of the eae gene from a dog attaching and effacing Escherichia coli strain 4221. FEMS Microbiol Lett 148, 239-245.

Arbeit, R. D., Arthur, M., Dunn, R., Kim, C., Selander, R. K. \& Goldstein, R. (1990). Resolution of recent evolutionary divergence among Escherichia coli from related lineages: the application of pulsed field electrophoresis to molecular epidemiology. J Infect Dis 161, 230-235.

Ausubel, F. M., Brent, R., Kingston, R. E., Moore, D. D., Seidman, J. G., Smith, J. A. \& Struhl, K. (1991). Current Protocols in Molecular Biology. New York: Wiley.

Beaudry, M., Zhu, C., Fairbrother, J. M. \& Harel, J. (1996). Genotypic and phenotypic characterization of Escherichia coli isolates from dogs manifesting attaching and effacing lesions. $J$ Clin Microbiol 34, 144-148.

Beutin, L., Geiger, D., Zimmermann, S. \& Karch, H. (1996). Virulence markers of shiga-like toxin-producing Escherichia coli strains originating from healthy domestic animals of different species. J Clin Microbiol 33, 631-635.

Blanco, J., Cid, D., Blanco, J. E., Blanco, M., Ruiz Santa Quiteria, J. A. \& De la Fuente, R. (1996). Serogroups, toxins and antibiotic resistance of Escherichia coli strains isolated from diarrhoeic lambs in Spain. Vet Microbiol 49, 209-217.

Broes, A., Drolet, R., Jacques, M., Fairbrother, J. M. \& Johnson, W. M. (1988). Natural infection with an attaching and effacing Escherichia coli in a diarrheic puppy. Can J Vet Res 52, 280-282.

Cantey, J. R. \& Blake, R. K. (1977). Diarrhoea due to Escherichia coli in the rabbit: a novel mechanism. J Infect Dis 135, 454-462.

China, B., Pirson, V. \& Mainil, J. (1998). Prevalence and molecular typing of attaching and effacing Escherichia coli among calf populations in Belgium. Vet Microbiol 63, 249-259.

China, B., Goffaux, F., Pirson, V. \& Mainil, J. (1999a). Comparison of eae, tir, espA, and espB genes of bovine and human attaching and effacing Escherichia coli by multiplex polymerase chain reaction. FEMS Microbiol Lett 178, 177-182.

China, B., Jacquemin, E., Devrin, A. C., Pirson, V. \& Mainil, J. (1999b). Heterogeneity of the eae genes in attaching/effacing Escherichia coli from cattle: comparison with human strains. Res Microbiol 150, 323-332.

Cid, D., Blanco, M., Blanco, J. E., Ruiz Santa Quiteria, J. A., De la Fuente, R. \& Blanco, J. (1996). Serogroups, toxins and antibiotic resistance of Escherichia coli strains isolated from diarrhoeic goat kids in Spain. Vet Microbiol 53, 349-354.
Donnenberg, M. S., Yu, J. \& Kaper, J. B. (1993). A second chromosomal gene necessary for intimate attachment of enteropathogenic Escherichia coli to epithelial cells. J Bacteriol 175, 4670-4680.

Drolet, R., Fairbrother, J. M. \& Vaillancourt, D. (1994). Attaching and effacing Escherichia coli in a goat with diarrhoea. Can Vet J 35, 122-123.

Duhamel, G. E., Moxley, R. A., Maddox, C. W. \& Erickson, E. D. (1992). Enteric infection of a goat with enterohemorrhagic Escherichia coli (O103: H2). J Vet Diagn Invest 4, 197-200.

Ebel, F., Deibel, C., Kresse, A. U., Guzman, C. A. \& Chakraborty, T. (1996). Temperature- and medium-dependent secretion of proteins by shiga toxin-producing Escherichia coli. Infect Immun 64, 4472-4479.

Elliot, S. J., Wainwright, L. A., McDaniel, T. K., Jarvis, K. G., Deng, Y. K., Lai, L. C., McNamara, B. P., Donnenberg, M. S. \& Kaper, J. B. (1998). The complete sequence of the locus of enterocyte effacement (LEE) from enteropathogenic Escherichia coli E2348/69. Mol Microbiol 28, 1-4.

Fischer, J., Maddox, C., Moxley, R., Kinden, D. \& Miller, M. (1994). Pathogenicity of a bovine attaching effacing Escherichia coli isolated lacking Shiga-like toxins. Am J Vet Res 55, 991-999.

Foubister, V., Rossenshine, I., Donnenberg, M. S. \& Finlay, B. B. (1994). The eaeB of enteropathogenic Escherichia coli is necessary for signal transduction in epithelial cells. Infect Immun 62, 3038-3040.

Frankel, G., Candy, D. C. A., Everest, P. \& Dougan, G. (1994). Characterization of the C-terminal domains of intimin-like proteins of enteropathogenic and enterohemorrhagic Escherichia coli, Citrobacter freundii, and Hafnia alvei. Infect Immun 62, 1835-1842.

Frankel, G., Philips, A. D., Rosenshine, I., Dougan, G., Kaper, J. B. \& Knutton, S. (1998). Enteropathogenic and enterohaemorrhagic Escherichia coli: more subversive elements. Mol Microbiol 30, 911-921.

Gannon, V. P. J., Rashed, M., King, R. K. \& Thomas, E. J. G. (1993). Detection and characterization of the eae gene of shiga-like toxin producing Escherichia coli using polymerase chain reaction. $J$ Clin Microbiol 31, 1268-1274.

Griffin, P. M. \& Tauxe, R. V. (1991). The epidemiology of infections caused by Escherichia coli $\mathrm{O} 157: \mathrm{H} 7$, other enterohemorrhagic E. coli, and the associated hemolytic uremic syndrome. Epidemiol Rev 13, 60-98.

Higgins, D. G. \& Sharp, P. M. (1988). Clustal: a package for performing multiple sequence alignments on a microcomputer. Gene 73, 237-244.

Janke, B. H., Francis, D. H., Collins, J. E., Libal, M. C., Zeman, K. H. \& Johnson, D. D. (1989). Attaching and effacing Escherichia coli infections in calves, pigs, lambs, and dogs. J Vet Diagn Invest $\mathbf{1}$, 6-11.

Jerse, A. E., Yu, J., Tall, B. D. \& Kaper, J. B (1990). A genetic locus of enteropathogenic Escherichia coli necessary for the production of attaching and effacing lesions on tissue culture cells. Proc Natl Acad Sci US A 87, 7839-7843.

Kudva, I. T., Hatfield, P. G. \& Hovde, C. J. (1996). Escherichia coli O157:H7 in microbial flora of sheep. J Clin Microbiol 34, 431-433.

McDaniel, T. K \& Kaper, J. B. (1997). A cloned pathogenicity island from enteropathogenic Escherichia coli confers the attaching and effacing phenotype on E. coli K-12. Mol Microbiol 23, 399-407.

McDaniel, T. K., Jarvis, K. G., Donnenberg, M. S. \& Kaper, J. B. (1995). A genetic locus of enterocyte effacement conserved among 
diverse enterobacterial pathogens. Proc Natl Acad Sci US A 92, 1664-1668.

McGraw, E. A., Li, J., Selander, R. K. \& Whittam, T. S. (1999). Molecular evolution and mosaic structure of $\alpha, \beta$, and $\gamma$ intimins of pathogenic Escherichia coli. Mol Biol Evol 16, 12-22.

Mainil, J. G., Jacquemin, E. R., Kaeckenbeeck, A. E. \& Pohl, P. H. (1993). Association between the effacing (eae) gene and the Shigalike toxin encoding genes in Escherichia coli isolated from cattle. Am J Vet Res 54, 1064-1068.

Milon, A., Oswald, E. \& De Rycke, J. (1999). Rabbit EPEC: a model for the study of enteropathogenic Escherichia coli. Vet Res 30, 203-219.

Moon, H. W., Whipp, S. C., Argenzio, R. A., Levine, M. M. \& Gianella, R. A. (1983). Attaching and effacing activities of rabbit and human enteropathogenic Escherichia coli in pig and rabbit intestines. Infect Immun 39, 1340-1351.

Moxley, R. A. \& Francis, D. H. (1986). Natural and experimental infection with an attaching and effacing strain of Escherichia coli in calves. Infect Immun 53, 339-346.

Nataro, J. P. \& Kaper, J. B. (1998). Diarrhoeagenic Escherichia coli. Clin Microbiol Rev 11, 142-201.

Oswald, E., Schmidt, H., Morabito, S., Karch, H., Marches, O. \& Caprioli, A. (2000). Typing of intimin genes in human and animal enterohemorrhagic and enteropathogenic Escherichia coli: characterization of a new intimin variant. Infect Immun 68, 64-71.

Perna, N. T., Mayhew, G. F., Posfai, G., Elliott, S., Donnenberg, M. S., Kaper, J. B. \& Blattner, F. R. (1998). Molecular evolution of a pathogenicicty island from enterohemorrhagic Escherichia coli O157: H7. Infect Immun 66, 3810-3817.

Rios, M., Prado, V., Trucksis, M., Arellano, C., Borie, C., Alexandre, M., Fica, A. \& Levine, M. M. (1999). Clonal diversity of Chilean isolates of enterohemorrhagic Escherichia coli from patients with hemolytic-uremic syndrome, asymptomatic subjects, animal reservoirs, and food products. J Clin Microbiol 37, 778-780.

Schauer, D. B. \& Falkow, S. (1993). Attaching and effacing locus of a Citrobacter freundii biotype 4280 that causes transmissible murine colonic hyperplasia. Infect Immun 61, 2486-2492.
Smith, C. L. \& Cantor, C. R. (1987). Purification, specific fragmentation, and separation of large DNA molecules. Methods Enzymol 55, 449-467.

Tenover, F. C., Arbeit, R. D., Goering, R. V., Mickelsen, P. A., Murray, B. E., Persing, D. H. \& Swaminathan, B. (1996). Interpreting chromosomal DNA restriction patterns produced by pulsed-field gel electrophoresis, criteria for bacterial strain typing. J Clin Microbiol 33, 2233-2239.

Voss, E., Paton, A. W., Manning, P. A. \& Paton, J. C. (1998). Molecular analysis of shiga toxigenic Escherichia coli O111:Hproteins which react with sera from patients with hemolyticuremic syndrome. Infect Immun 66, 1467-1472.

Wells, J. G., Shipman, L. D., Greene, K. D. \& 10 other authors (1991). Isolation of Escherichia coli serotype O157: $\mathrm{H} 7$ and other Shiga-like-toxin-producing E. coli from dairy cattle. J Clin Microbiol 29, 985-989.

Whitman, T. S., Wolfe, M. L., Wachsmuth, I. K., Ørskov, F., Ørskov, I. \& Wilson, R. A. (1993). Clonal relationships among Escherichia coli strains that cause hemorrhagic colitis and infantile diarrhoea. Infect Immun 61, 16-19.

Wieler, L. H., Schwanitz, A., Vieler, E., Busse, B., Steinruck, H., Kaper, J. B. \& Baljer, G. (1998). Virulence properties of Shiga toxin-producing Escherichia coli (STEC) strains of serogroup O118, a major group of STEC pathogens in calves. J Clin Microbiol 36, 1604-1607.

Yu, J. \& Kaper, J. B. (1992). Cloning and characterization of the eae gene of enterohaemorrhagic Escherichia coli O157:H7. Mol Microbiol 6, 411-417.

Zhu, C., Harel, J., Jacques, M., Desautels, C., Donnenberg, M. S., Beaudry, M. \& Fairbrother, J. M. (1994). Virulence properties of attaching-effacing activity of Escherichia coli $\mathrm{O} 45$ from swine postweaning diarrhoea. Infect Immun 62, 4153-4159.

Received 17 November 2000; revised 6 April 2001; accepted 12 April 2001. 